ПСИХОЛОГІЧНІ ОСОБЛИВОСТІ МОТИВАЦІЇ ДОСЯГНЕНЬ (НА ПРИКЛАДІ СПОРТСМЕНОК І ПСИХОЛОГИНЬ ЮНАЦЬКОГО ВІКУ)

\author{
PSYCHOLOGICAL FEATURES OF ACHIEVEMENTS' MOTIVATION \\ (ON THE EXAMPLE OF ATHLETES AND PSYCHOLOGISTS IN YOUTH)
}

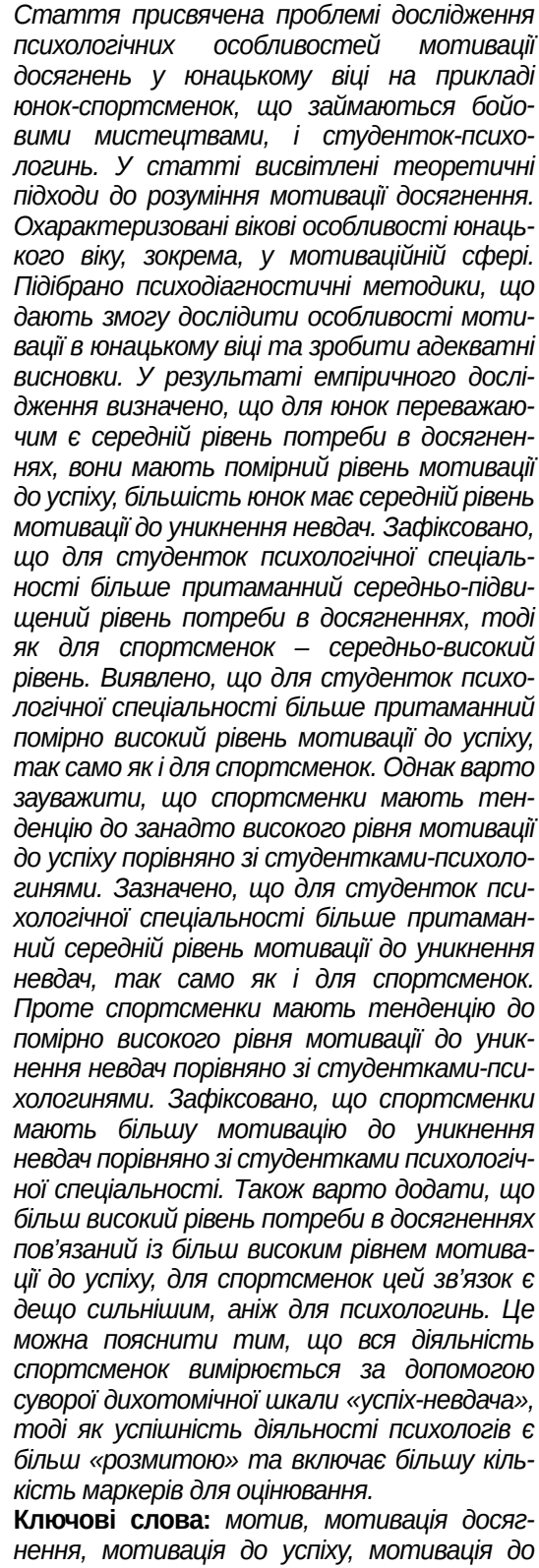

УДК 159.943 .8

DOI https://doi.org/10.32843/2663-

5208.2020.17.19

\section{Пивоварчик І.М.}

к.психол.н., доцент кафедри теорії та методики практичної психології Південноукраїнський національний педагогічний університет імені К.Д. Ушинського уникнення невдач, юнки, спортсменки, психологині.

The article is devoted to the problem of studying the psychological features of motivation of achievements in adolescence on the example of young female athletes engaged in martial arts and female students of psychology. The article highlights the theoretical approaches to understanding the motivation of achievement Age features of adolescence are characterized, in particular in the motivational sphere. Psychodiagnostic methods have been selected to investigate the peculiarities of motivation in adolescence and to draw adequate conclusions. An empirical study found that the average level of need for achievement is predominant for young ladies, they have a moderate level of motivation to succeed, and the vast majority of young ladies have a medium level of motivation to avoid failure. It is recorded that for students of psychological specialty more characterized by a medium-high level of need for achievement, while for athletes - a medium-high level. It was found that for students of psychological specialty is more characteristic of a moderately high level of motivation to succeed, as well as for athletes. However, it should be noted that female athletes tend to have too high motivation to succeed, compared to female psychology students. It is noted that for students of psychological specialty is more typical of the average level of motivation to avoid failure, as well as for athletes. However, it should be noted that athletes tend to have a moderately high level of motivation to avoid failure, compared to female students of psychology. It is recorded that female athletes are more motivated to avoid failure than female students in psychology. It should also be added that a higher level of need for achievement is associated with a higher level of motivation to succeed. And it should be noted that for female athletes this connection is somewhat stronger than for psychologists. Which can be explained by the fact that all the activities of athletes are measured using a strict dichotomous scale "success-failure", while the success of psychologists is more "blurred" and includes more markers for evaluation.

Key words: motive, motivation to achieve, motivation to succeed, motivation to avoid failure, young people, athletes, psychologists.
Постановка проблеми. Сучасне суспільство орієнтовано на успіх: успішну роботу, успішне хобі, успішну творчість, успішну сім'ю тощо. Прагнення до успіху пронизує всі сфери життєдіяльності особистості. Успіху заздрять, його наслідують. Успіх особистості в певній сфері життєдіяльності вимірюється досягненнями, а здатність досягати відповідних результатів визначається індивіду- ально-психологічними особливостями особистості, які визначаються певними рисами, властивостями, здібностями та внутрішніми спонуканнями, одним із яких $€$ мотивація досягнення.

Мотивація досягнення - це функціональна система інтегрованих у єдине ціле когнітивних та афективних процесів, яка регулює діяльність у ситуації досягнення. 
Аналіз останніх досліджень і публікацій. Проблему мотивації досягнення вивчали як зарубіжні, так і вітчизняні вчені. Серед них варто виділити таких як Д. Аткінсон, А. Бандура, Б. Вайнер, К. Двек, А. Маслоу, Д. Макклелланд, Г. Мюррей, Н. Фізер, Е. Фромм, Ф. Хайдер, Х. Хакхаузен, Ф. Хоппе, М. Буянова, Е. Воробйова, Т. Гордєєва, С. Занюк, Е. Кузнецова й інші.

Хоча питання мотивації досягнення є досить актуальним у сучасній психології, його активно вивчають науковці, однак і досі не достатньо вивченою $є$ проблема мотивації досягнень сучасного юнацтва, саме це й зумовило вибір теми дослідження «Психологічні особливості мотивації досягнень (на прикладі спортсменок і психологинь юнацького віку)».

Постановка завдання. Мета статті дослідити психологічні особливості мотивації досягнення в юнацькому віці у спортсменок і психологинь.

Завдання дослідження:

1. Теоретично обґрунтувати проблему мотивації досягнень у психологічних дослідженнях.

2. Охарактеризувати особливості мотивації досягнень як психологічного феномена.

3. Дослідити особливості мотивації досягнення в юнацькому віці.

4. Порівняти особливості мотивації досягнення в юнацькому віці серед спортсменок і психологинь.

Виклад основного матеріалу дослідження. Успішність людини в певному виді діяльності або житті загалом залежить від її індивідуально-психологічних особливостей і внутрішніх чинників, які визначаються мотивацією досягнення. Уважається, що наукову категорію «мотивація досягнень» запропонував учений Г. Мюррей [4]. Розвиток психологічних знань подарував науці дослідників різних концептуальних підходів і напрямів, що вивчали проблему мотивації досягнень, серед них - Ф. Хоппе, Д. Маккелланд, А. Адлер, Е. Фромм, К. Двек, Х. Хекхаузен, Д. Аткінсон, Ф. Хайдер, А. Бандура, Н. Фізер, Б. Вайнер, Л. Грень, С. Занок, О. Артюшенко та Д. Нечипоренко й інші. Більша частина цих та інших наукових підходів опирається на те, що мотивація досягнення характеризується потребою особистості досягати успіху в певних видах діяльності. Науковцями визначено, що мотивація досягнення включає в себе такі підструктури, як прагнення до успіху й уникнення невдач. Більше того, вона може бути внутрішньою, яка визначається індивідуально-психологічними особливостями та прагненнями особистості, і зовнішньою, що визначається зовнішніми обставинами й чинниками.

Узагальнюючи результати багатьох досліджень, визначили, що в основі мотивації досягнення лежить мотив досягнення, який характеризується наполегливим прагненням, спонуканням особистості до активності, що пов'язаний із прагненням досягти успіху (уникнути невдачі) у відповідній діяльності й залежить від рівня домагань.

Дослідниця О. Дніпрова [3] говорить, що мотивація досягнення визначається як структурне утворення, мотив котрого - досягнення успіху та уникнення невдачі, включає такі елементи, як потреба в досягненні мети та її антиципація, інструментальна активність, афективний стан, результат діяльності й відповідне ставлення до цього інших людей. Це зумовлює появу напруження в межах можливості задоволення потреби, що може призвести до конфлікту.

Цікавою в цьому сенсі є позиція Н. Герасимової [2], яка виділяє такі типи конфліктів: мотиваційний, що характеризується протистоянням двох більш-менш рівноцінних мотивів «хочу» і «хочу»; внутрішньоособистісний конфлікт неадекватної самооцінки, який характеризується суперечливістю між двома альтернативними можливостями й відповідними мотивами «можу» і «можу»; моральний конфлікт, який визначається незбігом бажань і вимог, мотивів «можу» і «треба»; рольовий внутрішньоособистісний конфлікт, сутність якого полягає в боротьбі між декількома сферами діяльності й мотивами «треба» і «треба»; конфлікт нереалізованості бажання, який визначається протистоянням бажань і можливостей і мотивами «хочу» і «можу»; адаптаційний, що характеризується невідповідністю вимог і можливостей і мотивами «треба» і «можу».

У свою чергу, Н. Божок [1] описує, як дослідник Дж. Вайлд охарактеризував суперечності юнацького віку, що можуть впливати на мотиваційну сферу та появу конфліктного напруження: особистості юнацького віку сконцентровані на власному внутрішньому світі й уважають, що світ повинен бути саме таким, яким вони його бачать. Це пов'язано з тим, що більшість молоді не має життєвого досвіду, щоб зрозуміти та усвідомити погляди, які відрізняються від їхніх; власну невпевненість особи юнацького віку намагаються сховати за допомогою психологічних захисних механізмів; юнаки визначаються надмірною чутливістю через високий рівень сконцентрованості на собі й намаганні знайти своє місце в житті; особи юнацького віку характеризуються емоційністю та схильністю до змін настрою; особи юнацького віку велике значення надають власній ідентичності й власному вигляду. Однак вони не дуже люблять, коли їх виділяють серед інших однолітків; вони схильні до ідеалізації та думають про те, яким треба бути, ніж про те, як є в житті; юнаки іноді визначаються нереалістичними уявленнями щодо власної особистості. 
Одним із найпритаманіших конфліктів для періоду юності $€$ внутрішньоособистісний конфлікт, що фокусується над мотивами «цінності-доступності». Цей конфлікт визначається здатністю юнаків до постановки свідомих цілей, подоланням труднощів на шляху їх досягнення та можливістю адекватно співвідносити власні бажання й ресурси [5].

У цьому сенсі спорт додає багато важелів на бік бажань і дуже опосередковано додає ресурсів. Спорт вимагає від особистості подолання труднощів як об'єктивного, так і суб'єктивного характеру. Велика кількість стресових ситуацій, неймовірний рівень відповідальності свідчать про екстремальність спорту як виду професійної діяльності. Усе це вимагає від спортсменів певного арсеналу індивідуально-психологічних якостей і високого рівня розвитку мотиваційної сфери. Отже, діяльність людей, які займаються спортом, потребує від них досить високих вимог як у фізичному напрямі, так і психологічному. Особливо гостро це питання постає в спортсменок, які за своєю фізичною природою є значно слабшими, на відміну від чоловіків. Саме тому ми припустили, що специфічні соціальні умови розвитку особистості (спорт, професійні вимоги) впливають на мотиваційну сферу, зокрема на рівень мотивації досягнень сучасних юнок.

У ході проведення дослідження нами використані такі методи: критичний аналіз теоретичних джерел наукової літератури, психодіагностичні методи (методика вимірювання мотиву досягнення Ю. Орлова, методика діагностики мотивації до успіху Т. Елерса та методика діагностики мотивації до уникнення невдач Т. Елерса), методи первинного (частотний аналіз) і вторинного (кореляційний аналіз за Пірсоном, t-критерій Стьюдента для двох незалежних вибірок) математично-статистичного аналізу.

У дослідження взяли участь 40 осіб юнацького віку, серед яких було 20 осіб студенток-психологів 3 та 4 курсів Державного закладу «Південноукраїнський національний педагогічний університет імені К.Д. Ушинського» і 20 спортсменок бойового мистецтва, які займаються в бійцівському клубі «Капітан», клубі бойового самбо «Майстер» і клубі карате «О-Кан». Статевий ценз опитуваних - дівчата, віковий - 19-22 роки.

Емпіричним завданням дослідження було вивчення особливостей мотивації досягнення в спортсменок і психологинь. Однак, щоб детальніше проаналізувати ці особливості, ми спочатку визначили особливості в усієї групи досліджуваних і простежили ці особливості за віковим параметром - юнацьким віком.

Проаналізуємо та порівняємо дані частотного аналізу за показниками потреби в досягненнях, мотивації до успіху й уникнення невдач окремо для спортсменок і психологинь.

У результаті порівняльного частотного аналізу за методикою вимірювання мотиву досягнення Ю. Орлова, ми отримали дані, відображені на рисунку 1.

Отже, низький рівень потреби в досягненнях спостерігається в 5\% спортсменок і 0\% студенток-психологинь, знижений - у 10\% спортсменок і 10\% психологинь, середній рівень - у 30\% спортсменок і 45\% психологинь, підвищений - у $25 \%$ спортсменок і $40 \%$ психологинь, а високий рівень - у $30 \%$ спортсменок і $5 \%$ психологинь.

Отже, можна стверджувати, що для студенток психологічної спеціальності більше притаманний середньо-підвищений рівень потреби

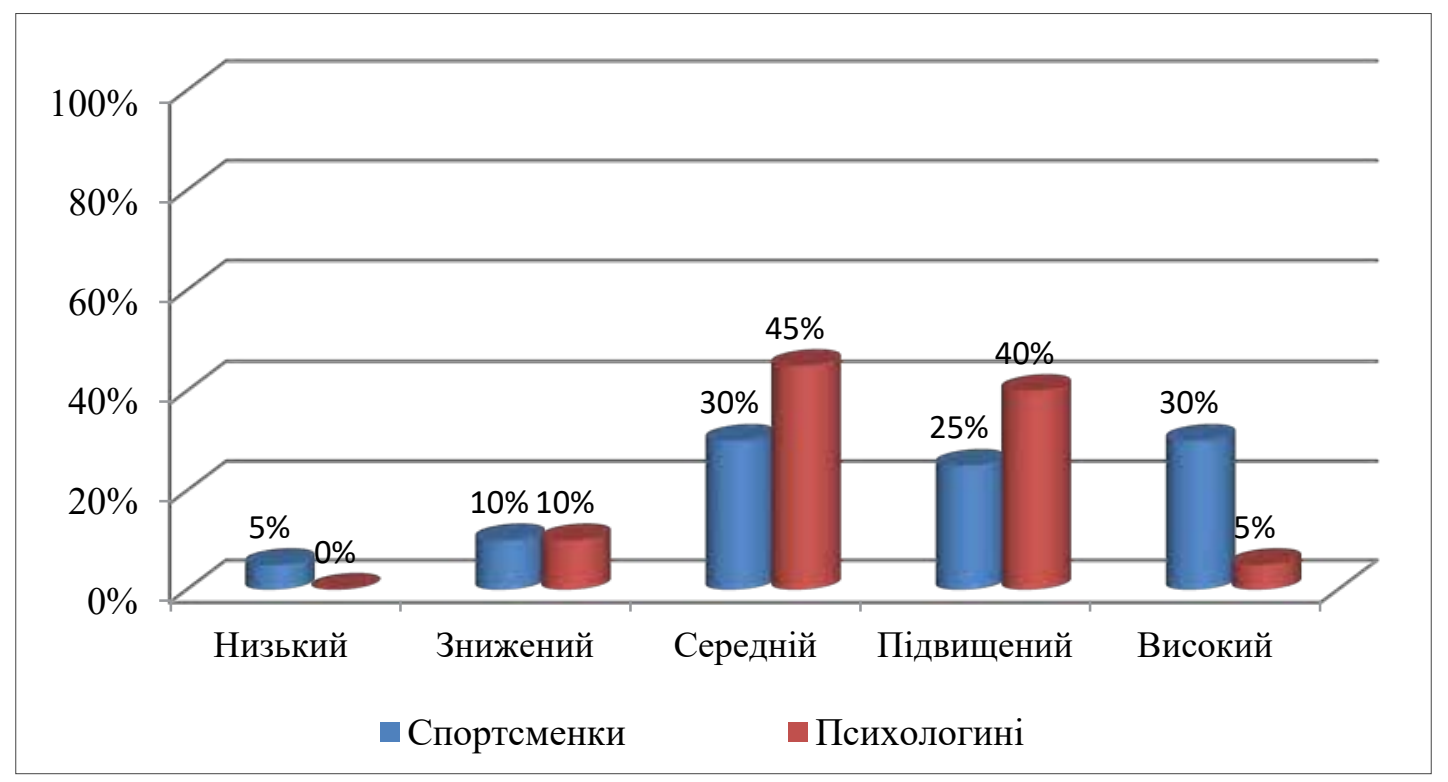

Рис. 1. Результати порівняльного частотного аналізу за показником потреби в досягненні 
в досягненнях, тоді як для спортсменок середньо-високий рівень.

У результаті порівняльного частотного аналізу за методикою діагностики особистості на мотивацію до успіху Т. Елерса ми отримали дані, відображені на рисунку 2.

Отже, низький рівень мотивації до успіху спостерігається в 5\% спортсменок і 5\% студенток-психологинь, середній рівень - у 25\% спортсменок і 35\% психологинь, помірно високий - у 45\% спортсменок і 50\% психологинь, а занадто високий рівень - у $25 \%$ спортсменок і 10\% психологинь.

Отже, можна стверджувати, що для студенток психологічної спеціальності більше прита- манний помірно високий рівень мотивації до успіху, так само як і для спортсменок. Однак варто зауважити, що спортсменки мають тенденцію до занадто високого рівня мотивації до успіху порівняно зі студентками-психологинями.

У результаті порівняльного частотного аналізу за методикою діагностики особистості на мотивацію до уникнення невдач Т. Елерса ми отримали дані, відображені на рисунку 3.

Отже, низький рівень мотивації до уникнення невдач спостерігається в 5\% спортсменок і 20\% студенток-психологинь, середній рівень - у 55\% спортсменок і 65\% психологинь, помірно високий - у 35\% спортсменок

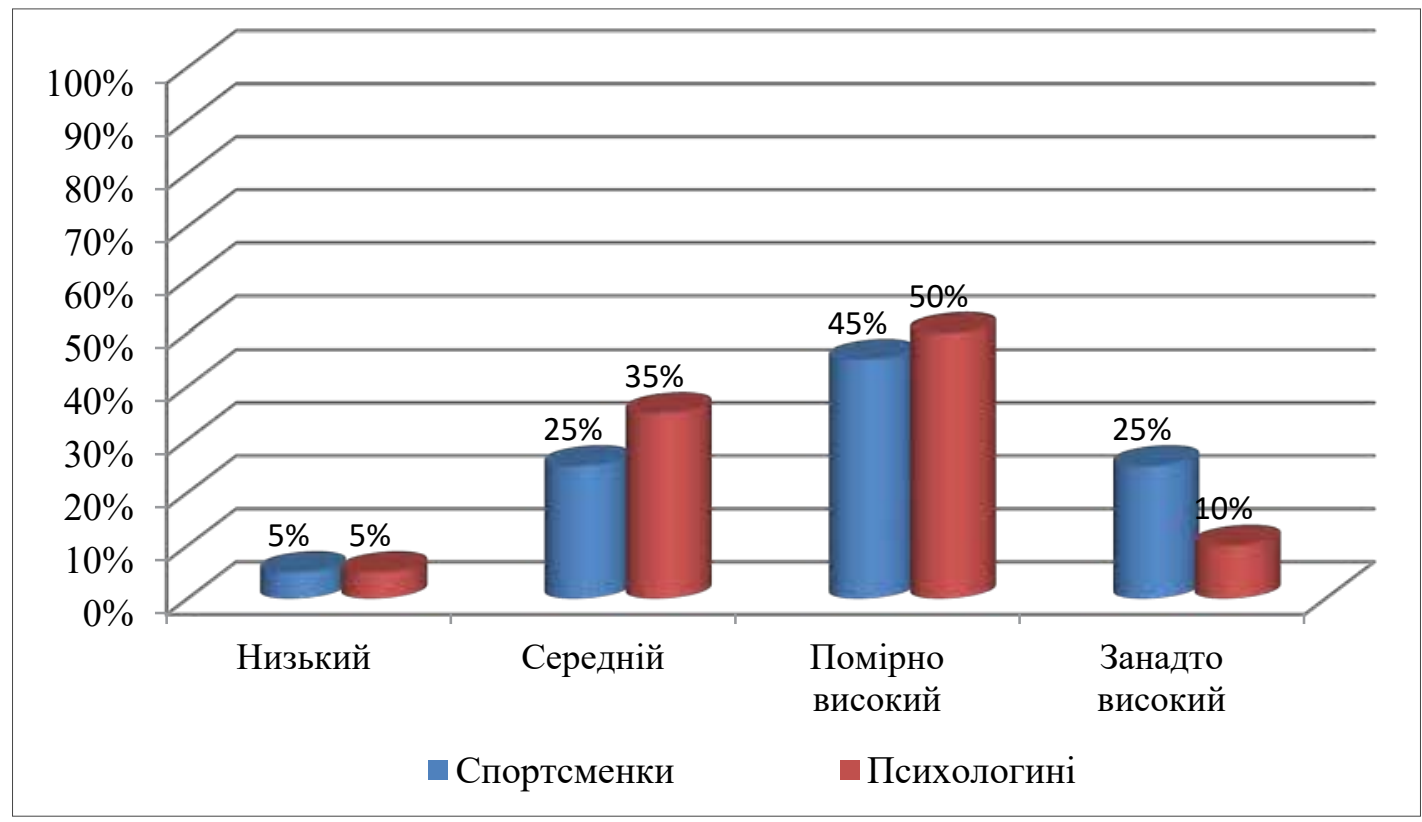

Рис. 2. Результати порівняльного частотного аналізу за показником мотивації до успіху

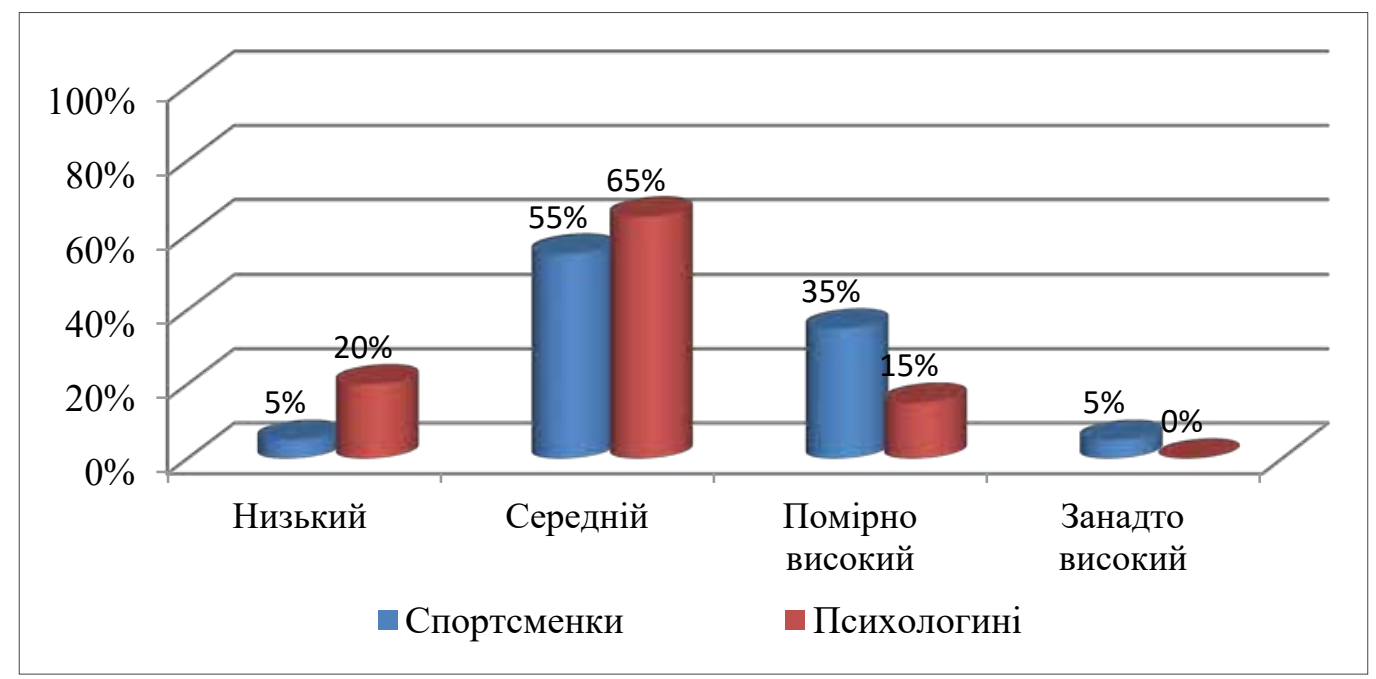

Рис. 3. Результати порівняльного частотного аналізу за показником мотивації до уникнення невдач 
і 15\% психологинь, а занадто високий рівень у 5\% спортсменок і 0\% психологинь.

Отже, можна стверджувати, що для студенток психологічної спеціальності більше притаманний середній рівень мотивації до уникнення невдач, так само як і для спортсменок. Однак варто зауважити, що спортсменки мають тенденцію до помірно високого рівня мотивації до уникнення невдач порівняно зі студентками-психологинями.

Таку ситуацію ми пов'язуємо з тим, що постійні, регулярні тренування, кількісне вимірювання фізичної сили під час тренувань формують більш адекватне й об'єктивне прогнозування успіху або невдачі, що прямо буде вказувати на успішність, на відміну від студенток психологічного спрямування, які мають суттєвий люфт у досягненні та успішності.

Одним із основних завдань дослідження було визначення особливостей мотивації досягнень у спортсменок і психологинь, тому в результаті t-критерію Стьюдента для двох незалежних вибірок ми отримали дані, відображені на рисунку 4.

Аналізуючи середні показники за характеристиками потреби в досягненнях, мотивації до успіху та мотивації до уникнення невдач, ми можемо стверджувати, що всі вони є дещо вищими в спортсменок. Однак варто зауважити, що статистично достовірні відмінності спостерігаються лише за показником мотивації до уникнення невдач. Це свідчить про те, що спортсменки мають більшу мотивацію до уникнення невдач порівняно зі студентками психологічної спеціальності.

У ході дослідження нам було цікаво простежити взаємозв'язки за досліджуваними параметрами, тому в результаті кореляційного аналізу за Пірсоном ми отримали статистично значущий взаємозв'язок для пари «потреба в досягненнях - мотивація до успіху», що відображено в таблиці 1.

Отже, як ми бачимо, що для всіх трьох груп опитуваних характерний прямо пропорційний сильний позитивний зв'язок між показниками потреби в досягненнях і мотивацією до успіху. Це свідчить про те, що більш високий рівень потреби в досягненнях пов'язаний із більш високим рівнем мотивації до успіху. Більш того, варто зауважити, що для спортсменок цей зв'язок є дещо сильнішим, аніж для психологинь.

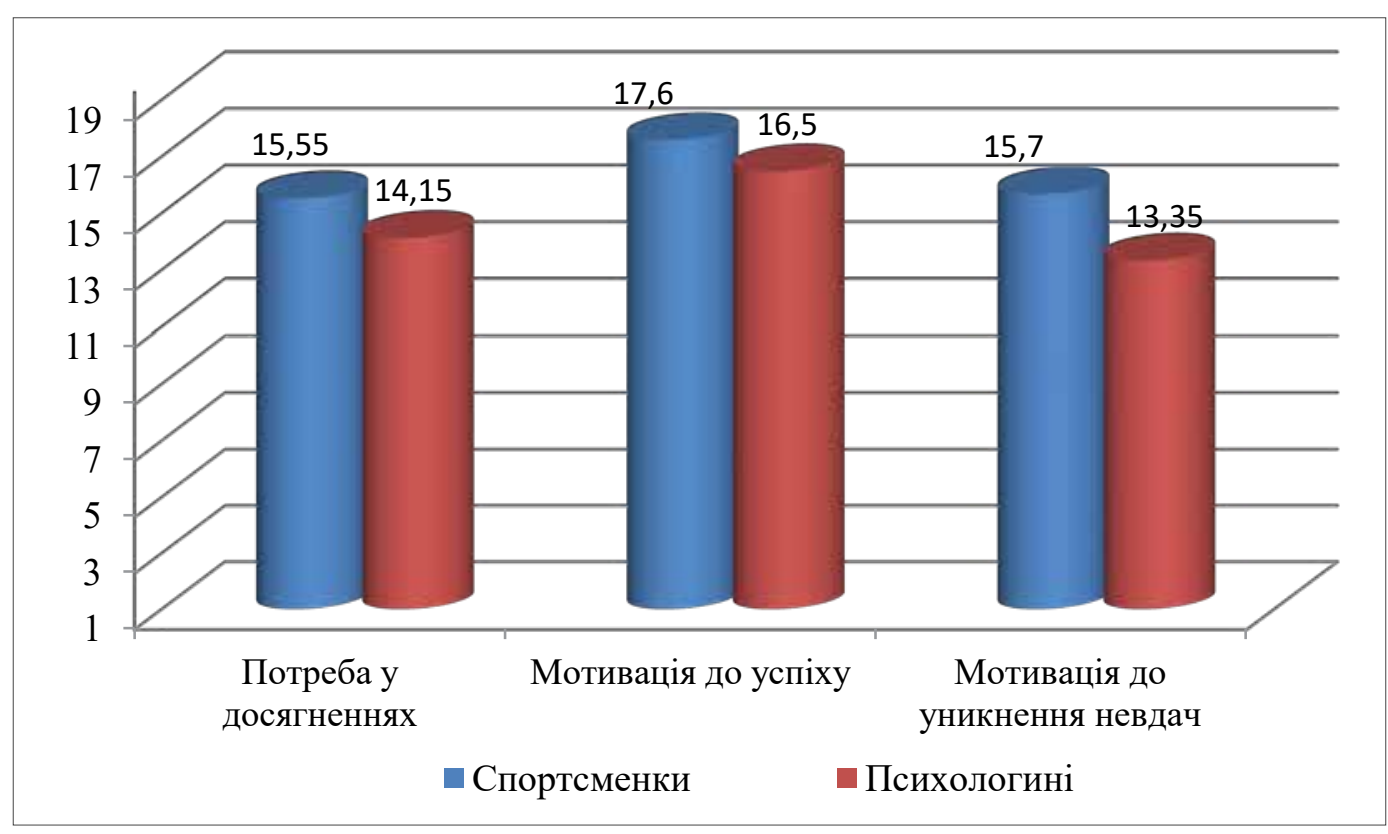

Рис. 4. Результати t-критерія Стьюдента за показниками потреби в досягненнях, мотивації до успіху й уникнення невдач

Таблиця 1

Результати кореляційного аналізу за показниками потреби в досягненнях і мотивації до успіху

\begin{tabular}{|l|c|c|}
\hline \multicolumn{1}{|c|}{ Категорія опитуваних } & Коефіцієнт кореляції $\mathbf{~}=$ & Статистична достовірність $\mathbf{p} \leq$ \\
\hline Вибірка загалом & 0,792 & 0,01 \\
\hline Спортсменки & 0,841 & 0,01 \\
\hline Психологині & 0,709 & 0,01 \\
\hline
\end{tabular}


Висновки з проведеного дослідження. Теоретичний аналіз наукової літератури та результати емпіричного дослідження дали змогу зробити такі висновки.

По-перше, аналізуючи підходи до вивчення мотивації досягнення особистості, можемо стверджувати, що ця проблема досить активно досліджується як у зарубіжній, так і вітчизняній психології. Більша частина наукових підходів опирається на те, що мотивація досягнення характеризується потребою особистості досягати успіху в певних видах діяльності. Мотивація досягнення включає такі підструктури, як прагнення до успіху й уникнення невдач. Більше того, вона може бути внутрішньою, яка визначається індивідуально-психологічними особливостями й прагненнями особистості, і зовнішньою, що визначається зовнішніми обставинами та чинниками.

По-друге, мотивація досягнення - це функціональна система інтегрованих у єдине ціле когнітивних та афективних процесів, яка регулює діяльність у ситуації досягнення.

В основі мотивації досягнення лежить мотив досягнення. Мотив досягнення характеризується наполегливим прагненням, спонуканням особистості до активності, яка пов'язана з прагненням досягти успіху (уникнути невдачі) у відповідній діяльності й залежить від рівня домагань.

Мотив досягнення має свою структуру і включає такі компоненти: когнітивний, який визначається здатністю до розумового сприйняття відповідної діяльності, що сприятиме успіху або уникненню невдачі; емоційно-ціннісний, який характеризується поясненням причини певної діяльності; діяльнісно-поведінковий, що передбачає виконання відповідної діяльності.

По-третє, питання мотивації досягнення $\epsilon$ актуальним у юнацькому віці. Юнацький вік $€$ одним із найпроблемніших у плані його вивчення. Уважається, що він обмежується віковими межами від 17 до 21-22 років. Цей віковий період визначається закінченням фізичного, статевого розвитку, а також становленням особистості, її особистісним і професійним самовизначенням, розвитком самосвідомості й досягненням соціальної зрілості. У цьому віці продовжується психічний розвиток, переструктуровуються психічні функції, зокрема інтелектуальні, змінюється особистісна структура, що пов'язано з входом у нові соціальні ролі.

Головними надбаннями юнацького віку стають відкриття свого «я», розвиток рефлексії, усвідомлення своїх особливостей, формування життєвого плану, установка на свідому побудову свого життя, поступова інтеграція в різні життєві сфери.

Цей віковий період супроводжується кризою, успішне вирішення якої приводить до формування позитивної самосвідомості особистості, що впливає на позитивну самооцінку та самоставлення.

По-четверте, діяльність людей, які займаються спортом, потребує від них досить високих вимог як у фізичному напрямі, так і психологічному.

По-п'яте, аналізуючи результати емпіричного дослідження особливостей мотивації досягнення в юнок, ми визначили, що для юнок переважаючим є середній рівень потреби в досягненнях. Така особистість характеризується помірною цілеспрямованістю в досягненні власних цілей, часто вона не задовольняється тим, чого досягла, і намагається зробити справу краще, аніж це робила раніше. Така людина має здатність захоплюватися власною діяльністю, досить часто намагається отримати задоволення від успіху й добре працювати. Для неї характерна потреба винаходити нові прийоми та способи роботи у виконанні звичайних справ, для такої особистості притаманний помірний дух суперництва. Для такої особистості характерний вибір завдань середньої важкості, вона готова прийняти допомогу оточуючих і допомогти іншим під час вирішення складного завдання, щоб разом відчути радість успіху.

Дівчата юнацького віку мають помірний рівень мотивації до успіху. Особистість із високим рівнем мотивації до успіху здатна ризикувати задля досягнення бажаної мети, однак ризик повинен оцінюватися як середній. Такі люди більше орієнтуються на власні сили, аніж на оточуючих, наполегливо і гнучко прагнуть до досягнення поставленої мети.

Більшість юнок має середній рівень мотивації до уникнення невдач. Особистість із середнім рівнем мотивації до уникнення невдач боїться невдач, так як вони вплинуть на рівень їі самооцінки, однак така особа береться за виконання діяльності навіть незважаючи на страх.

По-шосте, для студенток психологічної спеціальності більше притаманний середньо-підвищений рівень потреби в досягненнях, тоді як для спортсменок - середньо-високий рівень потреби в досягненнях.

Для студенток психологічної спеціальності більше притаманний помірно високий рівень мотивації до успіху, так само як і для спортсменок. Однак варто зауважити, що спортсменки мають тенденцію до занадто високого рівня мотивації до успіху порівняно зі студентками-психологинями.

Для студенток психологічної спеціальності більше притаманний середній рівень мотивації до уникнення невдач, так само як і для спортсменок. Однак спортсменки мають тенденцію до помірно високого рівня мотивації до уникнення невдач порівняно зі студентками-психологинями. 
Більше того, спортсменки мають більшу мотивацію до уникнення невдач порівняно зі студентками психологічної спеціальності.

Також варто додати, що більш високий рівень потреби в досягненнях пов'язаний із більш високим рівнем мотивації до успіху, для спортсменок цей зв'язок є дещо сильнішим, аніж для психологинь. Це можна пояснити тим, що вся діяльність спортсменок вимірюється за допомогою суворої дихотомічної шкали «успіх-невдача", тоді як успішність діяльності психологів $є$ більш «розмитою» та включає більшу кількість маркерів для оцінювання.

\section{ЛITEPATУРA:}

1. Божок Н. Психологічні особливості юнацького віку та їх вплив на формування фрустраційної толе- рантності майбутнього фахівця. Психологія особиcmocmi. 2013. № 1. C. 187-194.

2. Герасімова Н.Є. Теоретичні передумови виникнення внутрішньо особистісного конфлікту. Наукове проектування інноваційних та альтернативних систем вищої освіти: матеріали Всеукраїнської науково-практичної консреренції. Тернопіль, 2000. C. $197-200$.

3. Дніпрова О.А. Динаміка мотивації досягнення у студентів-психологів. Вісник Дніпропетровського університету імені Альсреда Нобеля. Серія «Педагогіка і психологія». 2014. № 1. С. 17-21.

4. Хекхаузен Х. Мотивация и деятельность. Москва : Смысл, 2003. 860 с.

5. Хомуленко Т.Б., Балушок М.В. Особливості виникнення внутрішньо особистісного конфрлікту в юнацькому віці. Проблеми сучасної психології. 2015. Вип. 27. С. 594-610. 